ACTA THERIOLOGICA

Vol. 27, 28: 409-425, 1982

\title{
Population Characteristics of Roe Deer Inhabiting a Small Forest ${ }^{1}$
}

\author{
Zygmunt PIELOWSKI \& Wojciech BRESIŃSKI
}

\begin{abstract}
Pielowski Z. \& Bresiński W., 1982: Population characteristics of roe deer inhabiting a small forest. Acta theriol., 27, 28: 409-425 [With 5 Tables \& 2 Figs.]

Studies were made over a period of several years of basic population processes in a group of roe deer inhabiting a small wood situated in fields. The purpose of these studies was to determine to what extent this community differs from roe deer living in fields surrounding the wood. It was found that the density of roe deer in the wood is several times greater than in the extensive area of fields surrounding it. During the phase of stabilization of their numbers the roe deer in the wood form a kind of sub-population with a considerable degree of ecological isolation. It is, however, formed or at least may be drawn, from the large group of migrants from fields which enter the wood at times when the density there decreases. This phenomenon can be explained by the attractive nature of small forest biotopes and the instinctive link between roe deer and their original forest habitat.

[Polish Hunting Association, Research Station, 62-055 Czempiń]
\end{abstract}

\section{INTRODUCTION}

Studies and discussion are increasing in intensity on the biological significance of the phenomenon consisting in the formation of a new ecological form of roe deer - Capreolus capreolus (Linnaeus, 1758) settling in treeless or scantily wooded agrocenoses. Pielowski (1977) considers that the genesis of the field ecotype of roe deer is to be found in the population mechanisms which result from overcrowding of roe deer in forest biotopes undergoing constant degredation as the habitat of this species, and also in the creation by man of suitable living conditions for roe deer in treeless areas under intensive agricultural management. According to this theory an important part is played here by the exceptionally great biological plasticity of the roe deer, which has led to the formation of a new ecotype - the field roe deer. This hypothesis, however, requires confirmation. One of the requirements was to examine the significance for a field roe deer population, and its creation, of small forests in fields constituting an integral component of agrocenoses. These forests, varying in area from $200-300$ ha, are distinguished by unusually great density of settlement by roe deer, up to 100 individuals

1 Pracę wykonano w ramach problemu MR-II/15 koordynowanego przez Instytut Ekologii PAN. 
per 100 ha during the spring period (unpublished data from the Polish Hunting Association Research Station). Groups of these animals in small forests have not been specially distinguished in general descriptions of field roe deer populations (Kałuziński, 1982). There are, however, grounds for suspecting that at least in larger stretches of such wooded land roe deer may live which cannot be fully identified with field roe deer. The correctness of such a hyphothesis is borne out at least by the fact that the size of forest roe deer's home ranges does not exceed 50-70 ha and with considerable density in wooded areas covers a far smaller area (Hennig, 1962; Mottl, 1962; Prior, 1968; Kurt, 1968; Strandgaard, 1972; Fruziński et al., 1983; Pielowski, 1983 and others).

The purpose of this study was to draw up a population description of roe deer inhabiting a small forest and to determine on the strength of this whether and to what degree this group differs from the community of field roe deer surrounding it, and the interrelations and interactions between these subpopulations.

\section{STUDY AREA}

The study area consisted of a stretch of wooded land situated in fields, 285 ha in area and popularly known as "Slonin Wood", forming one of several wooded areas of this type situated in the extensive agricultural region near Czempin in the Poznan voivodship. A 15,000 ha area of this region forms the experimental range of the Polish Hunting Association Research Station at Czempin. Over $90 \%$ of the boundaries of Słonin Wood meet agricultural land, part of which includes hay meadows. Not quite $10 \%$ of the forest edge is bounded by built-up areas.

The tree stand of Slonin Wood varies in age, but a large part of it consists of young plantations and pole-sized stands. Pinus silvestris predominates, while the deciduous species include Quercus robur, Betula verrucosa, Alnus glutinosa and Populus sp. Many of the forest sectors and plots have an abundant undergrowth and herb layer. Shelter conditions for roe deer are very good, but the food supply for these animals may be considered as only moderately plentiful. Compensation for this state of affairs is to be found in the abundance of food for roe deer over almost the entire year in the field areas adjointing the wood. During the winter, and particularly when the ground is covered with snow, roe deer are kept supplied with fodder cabbage and hay. Salt is placed in various salt-licks throughout the year, and systematic control of stray poaching dogs is maintained. The extent to which humans move about the wood at certain times of the year is considerable.

The study area included, in addition to wooded areas, the meadow and pasture zone from 200 to $500 \mathrm{~m}$ wide, depending on the contour of the area round the wood.

\section{METHODS}

One of the basic methodical assumptions of this study was the necessity to trace variations in numbers of study group of roe deer and changes in certain 
elements of its population structure. From 1965 to 1975 the spring herd of roe deer in the study area was defined by means of an estimate based on annual reports of game wardens and the authors of this paper. The sex ratio was also defined by this means. In 1976 and 1977 trial drives were carried out in early spring over about $50 \%$ of the wooded area, using 50 beaters and 20 observers. The numerical results obtained were extrapolated on to the whole area of the wood and the head of roe deer defined in this way. During the same period, with the assistance of 10 qualified observers, evening counts were made on a given day of all roe deer emerging from the wood on to their feeding grounds surrounding the wood. The basis for accepting this quantitative method was the assumption that the marked poverty of food supply for roe deer in the wood at that time of year would cause almost all individuals to emerge to feed on the winter crops surrounding the wood. When the two quantitative methods were compared it was found that $90 \%$ of the population emerged from the wood to feed in areas outside it. As the second of the methods is technically far easier and at the same time far less time- and labour-consuming it was used in successive years. The quanititative results obtained were increased by $10 \%$ i.e. by the quantitative index for animals which did not leave the wood to feed in fields. This method has the further advantage over the trial driving method that it permits of determining the sex of the individuals counted and observed.

In 1975 an experiment was made in the form of reducing the number of roe deer in the study area almost to nil, forming in this way a kind of "population vacuum", and tracing the mechanisms and rate at which it was replenished. Complete extermination of roe deer also supplied material for a single complete quantitative and qualitative estimate of the head of roe deer in Slonin Wood. The animals were eliminated by shooting with hunting guns - the bucks during the period from May to September and does and fawns from October to December. It proved impossible to carry out shooting over the short period required by the method for technical reasons. In all 132 individuals were obtained by this method. Only 8 individuals survived which had been individually marked with collars in previous years (Pielowski, 1983) continued observations of which were considered essential in order to achieve the aim of this study.

Despite the considerable efforts made by hunters taking part in the operation in December 1975, apart from the marked animals, there were still roe deer left in the inaccessible parts of the wood which had proved impossible to shoot, and they were then caught in nets (Kałuziński, 1978). A further 14 individuals were caught which were transferred to the field area at a distance of $6 \mathrm{~km}$ from their native wood, in order to trace by means of direct observations the further life of these animals. These roe deer were marked with collars bearing numbers clearly visible at a distance of up to $200 \mathrm{~m}$ (Pielowski, 1983). Up to the end of April 1976 observations were made once a month successive years always in early spring, and from time to time over the whole year, of the area in which they had been transferred and the native area of these individuals.

The basic method for determining the degree of residency of roe deer and the size and shape of their individual ranges cosisted in collecting information about marked animals, whether those transferred in 1975 or those caught and marked in the study area in years before 1975 and also after that year (Pielowski, 1983). The proportion of marked individuals in the study area in different years varied within limits of 10 to $20 \%$ of all the animals.

4-Acta Theriologica 
Age with accuracy to 2 years was established for each animal obtained (shot or: caught) in 1975 on the basis of cheeck teeth wear (Pielowski, 1970).

Total number of roe deer shot during one season also made it possible to determine the quality of the bucks' antlers from the aspect of form and shape, and also strength and weight. It was anticipated that the development and structure of bucks' antlers might be distinguished by some specific characterstics in the specific quantitative-spatial system of the study population.

\section{RESULTS}

\subsection{Numbers}

Numbers of the roe deer population from 1965-1975, approximately estimated, varied from 20 to 40 individuals, with a slight tendency to increase (Fig. 1). This gives a density of from 7 to 14 individuals per 100 ha.

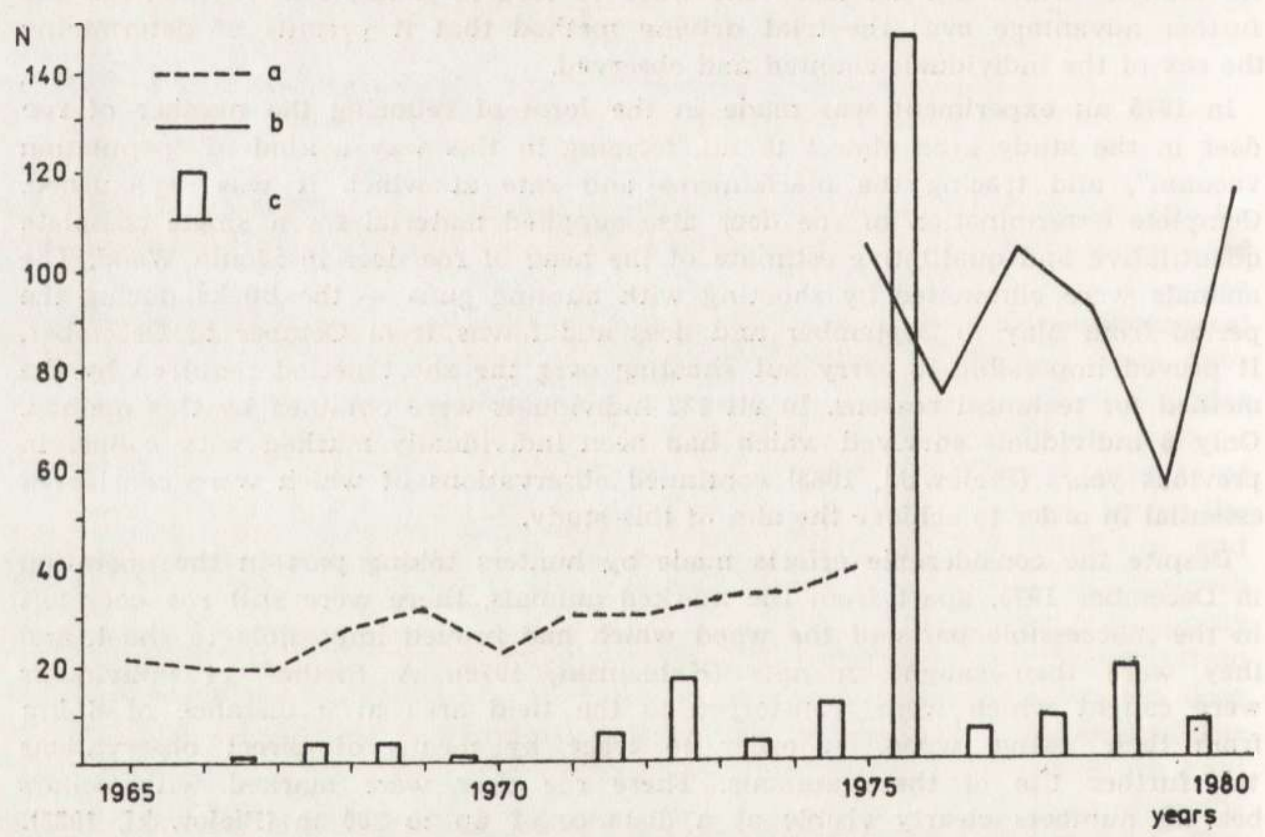

Fig. 1. Head of roe deer in spring and number obtained from Slonin Wood 285 ha in area.

a - estimated head of roe deer, b - actual numbers, $c$ - number obtained.

The shooting and total capture of roe deer carried out in summer and autumn 1975 in Słonin Wood yielded a total of 146 roe deer and showed that the real numbers of the study population were far higher than shown by the spring tally (Fig. 1). If in addition it is taken into account that each of the 15 adult does included in the head of roe deer 
in the spring of 1975 have produced at least one fawn, then the numbers up to the moment of their complete extermination would increase from 40 to 55 individuals. Actual numbers were, however, more than $2^{1 / 2}$ times greater.

$1976-1980$, in which years numbers of roe deer were determined by accurate methods, confirmed this fact. Six months after total reduction, i.e. in the spring of 1976 , there were 75 roe deer in the wood. In successive years there was a further rapid increase in population numbers (Fig. 1). This increase was, however, abruptly inhibited in 1979 after the exceptionally severe winter of $1978 / 1979$, during which the head of roe deer in the whole of the western part of Poland, including those in the field area surrounding the study area, was reduced by about $50 \%$ (Kałuziński, 1982). As early as the first year after the winter catastrophe there was another increase of $100 \%$ in the numbers in the Słonin Wood, in which the density of these animals was 51.6 individulas per 100 ha in the summer of 1975 , and on an average for the period 1977-1980 32.2 individuals per 100 ha.

\subsection{Sex Structure}

The ratio of males to females in the study population was estimated over a period of 11 years (1965-1975), giving an average of $1: 1.18$. The small numbers of animals obtained during this period included

Table 1

Density of roe deer in Slonin Wood and sex ratio.

\begin{tabular}{clcc}
\hline Year & Month & $\begin{array}{c}\text { Density } \\
\text { N/100 ha }\end{array}$ & $\begin{array}{c}\text { Sex ratio, } \\
\sigma^{T}: \text { o }\end{array}$ \\
\hline $1965-1975$ & March & 9.9 & $1: 1.18^{1}$ \\
1975 & May-Nov. & 51.2 & $1: 1.06^{2}$ \\
1975 & December & almost & $1: 1.68$ \\
1976 & April & 26.3 & $1: 1.19$ \\
1977 & $"$ & 36.1 & $1: 1.22$ \\
1978 & $"$ & 31.9 & $1: 1.28$ \\
1979 & $"$ & 20.0 & $1: 1.83$ \\
1980 & $"$ & 40.7 &
\end{tabular}

1 Means from estimations during 11 years,

2 Total elimination.

both sexes to an equal degree. Proof of the correctness of this estimate is the sex ratio obtained by total shooting in 1975 , when it was $1: 1.06$. Six months after reducing the density of roe deer in the study area almost to nil and entry from outside the wood of new individuals, there was a fairly considerable preponderance of does, expressed by the ratio $1: 1.68$. During the subsequent three years there was a distinct tendency 
414

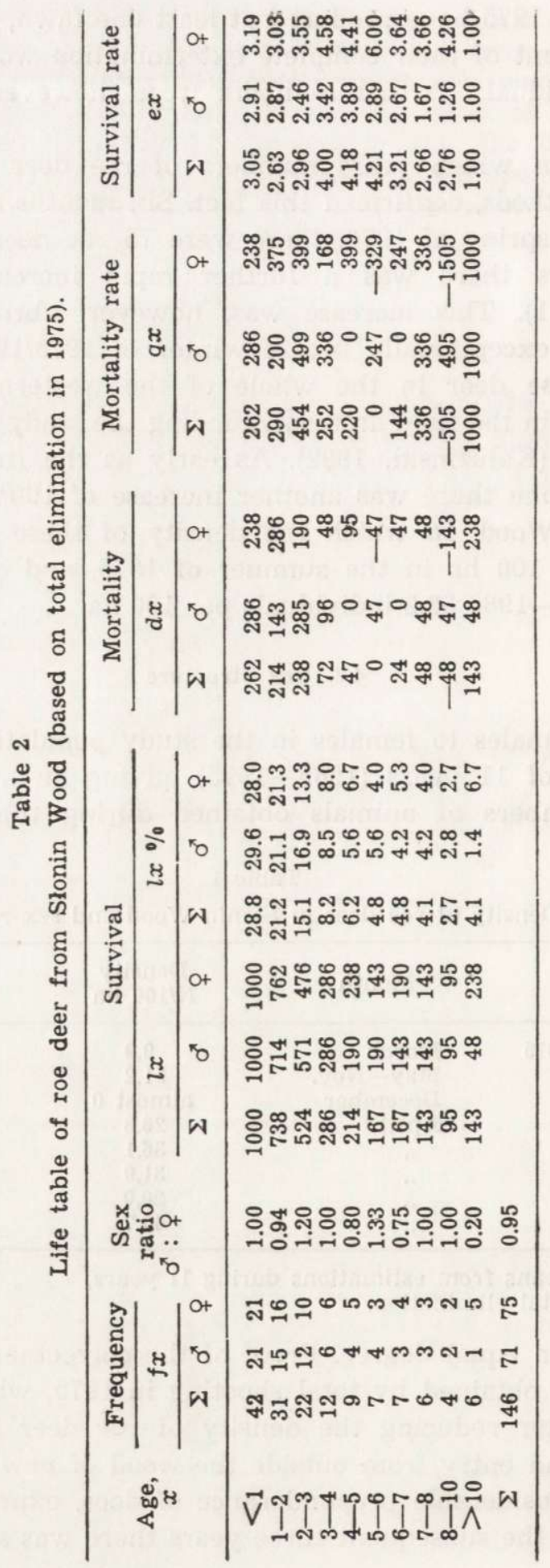


in sex ratio towards balance, maintained on a level of about $1: 1.2$. In the spring of 1980 , after considerable increase in density, which must be presumed to be due to individuals entering from other areas, females began again to predominate (Table 1). Fluctuations in sex ratio are slight in the various age classes, and it is only among individuals over 10 years old that females decidedly predominate (Table 2).

\subsection{Age Structure}

By eliminating all individuals in the study population in 1975 it proved possible to obtain an accurate picture of its age structure (Fig. 2). Young

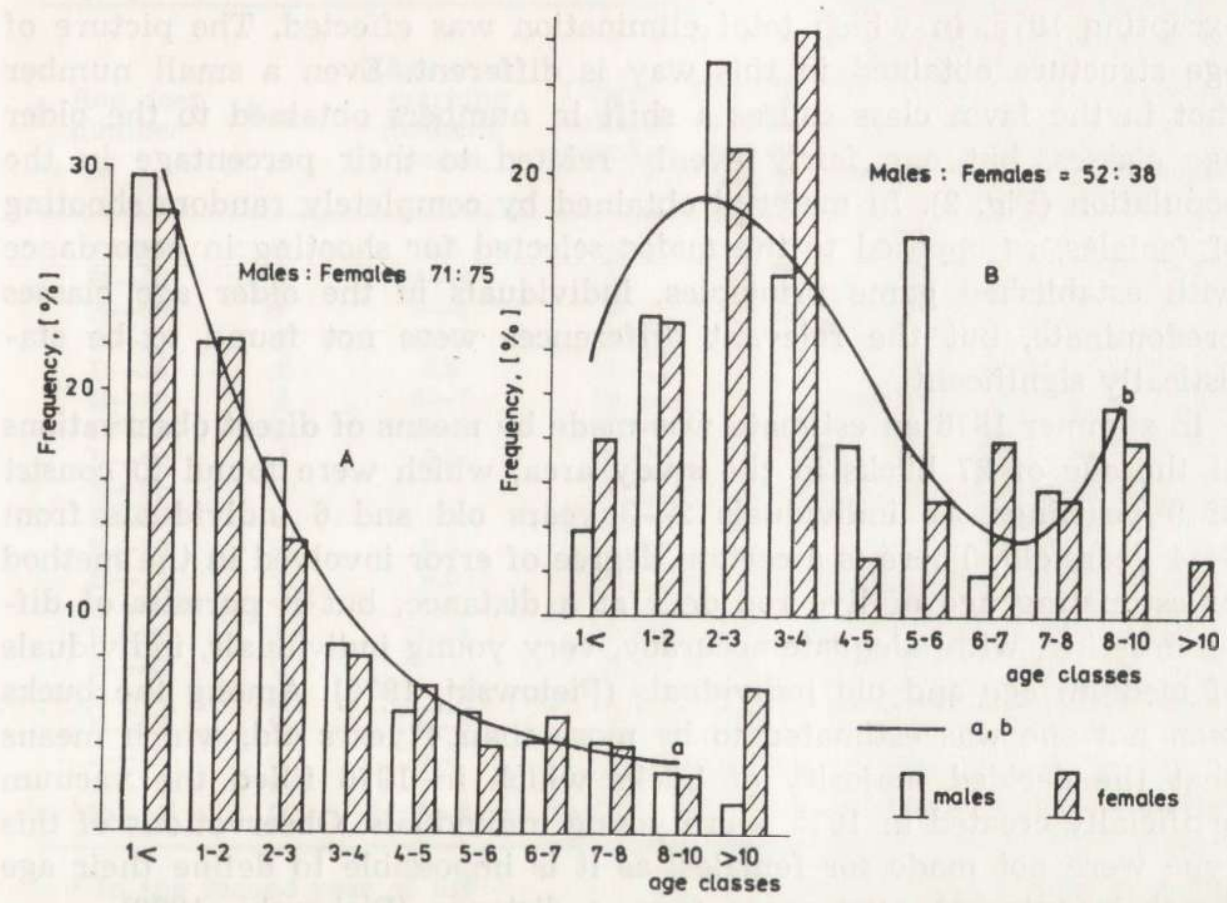

Fig. 2. Age structure of the roe deer community in Słonin Wood, based on total elimination in 1975 (A) and shooting during hunts for periods 1966/67-1974/75 and 1976/1977-1979/80 (B), giving curve of regression.

a) $y=60.000-19.378787 x+2.95606 x^{2}-0.098484 x^{8}$

b) $y=-2.0096+0.17659 x-0.44641 x^{2}+0.29424 x^{3}$

individuals up to three years old decidedly predominate, forming $65 \%$ of the whole population. The proportion of individuals under one year of age was $29 \%$, which is also a clear indication of effective increase in the study population up to the autumn period. A total of 42 fawns was found for 54 does, giving an average of 0.78 young per female of reproductive age. 
Age structure was very similar in both sexes. Does over 10 years old predominated numerically, but not to a statistically significant degree, and their survival is thus shown to be greater than that of bucks. Average length of life of roe deer in Słonin Wood, defined by the arithmetical mean of the age of all individuals in the population on 1st December 1975, was 3.41 years. It is slightly lower for bucks 3.21 years, but higher for does -3.6 years. It can be seen from the life table (Caughley, 1966) made for the study population that anticipated further life expectation is greater in all age classes (Table 2).

For purposes of comparison analysis was also made of the age structure of roe deer obtained from Slonin Wood in other study years excepting 1975, in which total elimination was effected. The picture of age structure obtained in this way is different. Even a small number shot in the fawn class causes a shift in numbers obtained to the older age classes, but one fairly evenly related to their percentage in the population (Fig. 2). In material obtained by completely random shooting of females, as opposed to the males selected for shooting in accordance with established game principles, individuals in the older age classes predominate, but the relevant differences were not found to be statistically significant.

In summer 1976 an estimate was made by means of direct observations of the age of 27 bucks in the study area, which were found to consist of 9 yearlings, 12 individuals $2-3$ years old and 6 individuals from $3-4$ years old. There is a certain degree of error involved in the method of estimating age of live roe deer at a distance, but it permits of differentiating, with adequate accuracy, very young individuals, individuals of medium age and old individuals (Pielowski, 1970). Among the bucks seen not one was estimated to be more than 4 years old, which means that the decided majority of bucks which in 1976 filled the vacuum artificially created in 1975, were young individuals. Observations of this type were not made for females, as it is impossible to define their age by their external appearance from a distance (Pielowski, 1970).

\subsection{Degree of Residency}

Individual marking of a certain number of individuals in the study area made it possible to trace the constancy of residence of roe deer within the wooded area over the whole of their lives. These observations were made of 20 individuals of both sexes and of different ages. The number of observations animals varied from several to nearly twenty, made over a period of 2 to 8 years (Table 3). Of these 'roe deer 13 animals were never observed to leave the study area. For a further 3 individuals their home range, the size and shape of which was defined 
by the method given by Pielowski (1983), included a zone outside the wood but did not exceed a distance of $500 \mathrm{~m}$. It was only in the case of 4 animals that the home range extended to include the wood, the area immediately round the wood and also field areas up to $2 \mathrm{~km}$ away. The buck with number B-16, caught and marked in the wood as an older fawn, was observed there during the second year of its life, after which it moved to the field areas adjacent to the wood and stayed there for two consecutive years.

Table 3

Observations of individually marked roe deer over period $1970-1980$.

\begin{tabular}{|c|c|c|c|c|c|c|c|}
\hline \multirow[b]{2}{*}{$\begin{array}{l}\text { Roe deer } \\
\text { number }\end{array}$} & \multirow[b]{2}{*}{ Sex } & \multirow[b]{2}{*}{$\begin{array}{l}\text { Age in a } \\
\text { marking } \\
\text { moment, } \\
\text { years }\end{array}$} & \multirow[b]{2}{*}{$\begin{array}{l}\text { Obser- } \\
\text { vations } \\
\text { number }\end{array}$} & \multirow[b]{2}{*}{$\begin{array}{l}\text { During } \\
\text { how } \\
\text { many } \\
\text { years }\end{array}$} & \multicolumn{3}{|c|}{ Observation place } \\
\hline & & & & & $\begin{array}{l}\text { On study } \\
\text { area }\end{array}$ & $\begin{array}{l}\text { Up to } 500 \mathrm{~m} \\
\text { outside of } \\
\text { study area }\end{array}$ & $\begin{array}{l}\text { In a } \\
\text { farther } \\
\text { distance }\end{array}$ \\
\hline$A-23$ & 우 & 0.5 & 4 & 3 & 4 & - & - \\
\hline$B-07$ & 우 & $6-7$ & 19 & 5 & 13 & 5 & 1 \\
\hline$B-08$ & वे & $3-4$ & 3. & 3 & 3. & - & - \\
\hline B-15 & $0^{x}$ & $1-2$ & 4 & 5 & 3 & 1 & - \\
\hline$B-16$ & $0^{x}$ & 0.5 & 16 & 3 & $2^{1}$ & 8 & 6 \\
\hline B -29 & 오 & $6-7$ & 12 & 7 & 4 & 1. & 7 \\
\hline B -63 & o & $2-3$ & 5 & 3 & 5 & - & - \\
\hline B- 66 & $\sigma^{x}$ & 0.5 & 9 & 4 & 9 & - & - \\
\hline B- 68 & 움 & & 7 & 3 & 7 & - & - \\
\hline B- 69 & 온 & & 2 & 3 & 2 & - & - \\
\hline$B-70$ & 오 & 0.5 & 12 & 8 & 12 & - & - \\
\hline$B-71$ & 오ํ & 0.5 & 14 & 7 & 14 & - & - \\
\hline B -72 & 오 & 0.5 & 7 & 2 & 2 & 1 & 4 \\
\hline B- -97 & ó & $3-4$ & 9 & 5 & 1 & 8 & - \\
\hline B -98 & 움 & & 6 & 3 & 6 & - & - \\
\hline B-99 & 오 & & 3. & 5 & 3 & - & - \\
\hline $\mathrm{E}-06$ & o & $4-5$ & 6 & 4 & 6 & - & - \\
\hline$E-11$ & $0^{x}$ & 0.5 & 4 & 3 & 4 & - & - \\
\hline$E-16$ & 우 & & 3 & 3 & 1 & 2 & - \\
\hline$E-17$ & q́ & $3-4$ & 4 & 5 & 4 & - & - \\
\hline
\end{tabular}

1 In the second year of life

Time analysis of successive observations of individuals with home ranges including both the wood and field showed that this system did not change in any way after the study area had been almost completely emptied of roe deer in 1975. All of the marked roe deer recorded during this period remained in areas which had hitherto formed their home ranges. In 1976 not even one new previously marked individual was found in the wood from the field areas surrounding it, even though there were at least 55 of these marked roe deer at that time, which forms about $10 \%$ of the head of animals inhabiting the field area round the wood within a radius of about $5 \mathrm{~km}$. If the established fact is taken 
into consideration that it was primarily young individuals (at least among males), which entered the wood during this period, it must be accepted that in view of the very small number of marked individuals in this group (only 10 animals, of which only 3 were bucks), the chances of any of them moving from field to wood was negligible.

In December 197514 roe deer, the remains of the former population which had proved almost impossible entirely to eliminate, were caught in Słonin Wood. This number includes 6 fawns, 2 yearlings and 6 older individuals (from 3 to 7 years); 4 males and 10 females. After marking these animals were released into open fields at a distance of about $6 \mathrm{~km}$ from the place in which they had hitherto sheltered. After being released all individuals at first remained in the area to which they had been transferred and entered the herd of field roe deer permanently living there. During the first months of 1976 some of these animals

\section{Table 4}

Results of transferring roe deer from the wood to fields.

\begin{tabular}{lccccc}
\hline Age & $\begin{array}{c}\text { Number of } \\
\text { transferring } \\
\text { roe deer }\end{array}$ & $\begin{array}{c}\text { Return } \\
\text { to native } \\
\text { forest }\end{array}$ & $\begin{array}{c}\text { Return to } \\
\text { another } \\
\text { forest }\end{array}$ & $\begin{array}{c}\text { Staying } \\
\text { on } \\
\text { fields }\end{array}$ & $\begin{array}{c}\text { Lost just } \\
\text { after the } \\
\text { introduc- } \\
\text { tion }\end{array}$ \\
\hline $\begin{array}{l}\text { Up to } 1.5 \text { years old } \\
\text { Older }\end{array}$ & 8 & 1 & - & 5 & 2 \\
\hline
\end{tabular}

left their place of introduction. Of the 6 older animals, one remained in fields but died there in spring 1976, 4 returned to their native wood and one reached another wood about $6 \mathrm{~km}$ away, but situated in an entirely different direction. Two years later this animal was again seen in the field, and in the following year in yet another small forest. Of the 8 young roe deer up to 1.5 years old two died in the fields in the winter of 1976, only one returned to its native wood, two evidently settled in fields and 3 animals which in April 1976, that is, 4 months after transfer, were seen in fields near the introduction site, later disappeared (Table 4).

\subsection{Quality of Antlers}

The considerable increase in the mean weight of antiers up to the age of 7-8 years is clearly evident. The weal quality of a yearling's antlers is striking, i.e. the large number of button-spikes only in this age class and the complete absence of fork-horns. In age class of $2-3$ year old bucks there is still a considerable number of weak individuals. In age classes of 4 years and over there is a complete absence of animals 
considered as appropriate for selective shooting, i.e. antlers without tines and fork-horns. One such antler without tines was an individual over 10 years old (Table 5).

Table 5

Quality of antlers from bucks obtained during total elimination in Slonin Wood in 1975.

\begin{tabular}{|c|c|c|c|c|c|c|}
\hline \multirow[b]{2}{*}{ Form } & \multirow[b]{2}{*}{ Quality } & \multicolumn{5}{|c|}{ Age classes - in years } \\
\hline & & $\begin{array}{l}\text { Year- } \\
\text { lings }\end{array}$ & $2-3$ & $\stackrel{3-4}{\text { and } 4-5}$ & to $7-6$ & $\begin{array}{l}\text { above } \\
8\end{array}$ \\
\hline Button-spike & & 6 & 1 & - & - & - \\
\hline $\begin{array}{l}\text { Spike-buck } \\
\text { up to high ears }\end{array}$ & $\begin{array}{l}\text { slender } \\
\text { stout }\end{array}$ & $\begin{array}{l}2 \\
2\end{array}$ & - & $\overline{-}$ & - & - \\
\hline $\begin{array}{l}\text { Spike-buck } \\
\text { above high ears }\end{array}$ & $\begin{array}{l}\text { slender } \\
\text { stout }\end{array}$ & $\overline{3}$ & $\overline{-}$ & - & $\overline{-}$ & $\overline{-}$ \\
\hline $\begin{array}{l}\text { Antlers } \\
\text { without } \\
\text { tines }\end{array}$ & $\begin{array}{l}\text { weak } \\
\text { middle } \\
\text { strong }\end{array}$ & $\overline{-}$ & $\begin{array}{r}2 \\
1 \\
- \\
\end{array}$ & $\frac{1}{-}$ & $\bar{z}$ & $\frac{1}{-}$ \\
\hline Forkhorn & $\begin{array}{l}\text { weak } \\
\text { middle } \\
\text { strong }\end{array}$ & $\frac{1}{-}$ & $\begin{array}{r}2 \\
3 \\
- \\
\end{array}$ & $\frac{1}{-}$ & $\bar{z}$ & $\bar{z}$ \\
\hline Six-pointer & $\begin{array}{l}\text { weak } \\
\text { middle } \\
\text { strong }\end{array}$ & $\overline{-}$ & $\frac{-}{3}$ & $\begin{array}{r}3 \\
4 \\
- \\
\end{array}$ & $\begin{array}{l}1 \\
5 \\
2 \\
\end{array}$ & $\frac{1}{-}$ \\
\hline $\begin{array}{l}\text { Mean weight acco } \\
\text { in } g \text { (to CIC nor }\end{array}$ & ding & 58 & 122 & 229 & 321 & - \\
\hline
\end{tabular}

\section{DISCUSSION}

By tracing variations in numbers of the study population it proved possible to establish that after years of intensive quantitative reduction in the head of roe deer (severe winter of 1978/79 and also 1969/70, although this was less distinct due to methods used) or its complete liquidation (1975) there is an exceptionally rapid renewal of numbers. It is however completely inadequate for the reproductive potential of the population, which may increase its numbers at best by $30-40 \%$. The far greater rate of increase in numbers in the study population and the fact of rapid and complete renewal after total removal by shooting points to a large number of individuals entering from other areas. A similar phenomenon was found by Andrzejewski \& Wrocławek (1962) in small forest rodents. In that case it was found that the numbers of immigrants were not higher than in areas with normal density of settlement, although the number of animals settling permanently increased among the newcomers, which consequently led to rapid set- 
tlement of the area to a state normal for the given season and habitat. It is quite possible that in the case of roe deer the mechanism of settlement of an "empty" area is similar, but more complicated, since the structure of roe deer populations is most certainly far more complicated. This would explain the predominance of females in years of intensive immigration. The estimate of age for bucks encountered in the wood the year following total shooting also showed that they are almost exclusively young individuals from $3-4$ years old.

The age structure of the population could only be disturbed to a negligible degree by game shooting maintained during the period from $1965-1975$ on a very low level of about $5 \%$ of the head of roe deer. The curve arising from it is characterized by a fairly abrupt decrease in its initial part (Fig. 2). This is due to the large proportion of young individuals up to 3 years old in the population. This would appear to show that despite the very great density $(30-50$ individuals $/ 100 \mathrm{ha})$ mechanisms evoking increased emigration of excess individuals into the nearby fields, in which density at this time was only 7 individuals per 100 ha (Kałuziński, 1982), were not yet acting to any important degree. Anticipated further length of life arising from the calculated "life table" is disproportionately low for roe deer in the young age classes, being only about 3 years (Table 2). In the case of fawns, that is, age class zero, this can be explained by the generally high mortality rate (Pielowski, 1970; Raesfeld et al., 1978; Stubbe \& Passarge, 1979). For roe deer from $1-2$ and $2-3$ years old this must be due to a considerable extent to disappearance of these animals as the result of emigration from the study area. As shown. by. Strandgaard's data (1972), it is the young animals which are pushed out from areas where density of settlement is too great.

Average length of life of roe deer from Słonin Wood (3.41 years) is greater than the corresponding figure for other populations examined from this aspect. Andersen (1953), also using data from total shooting, calculated for the roe deer population at Kalø (Denmark) that average length of life was 2.0 years. Strandgaard (1972) determined for a new population in the same area, on the basis of capture of over $90 \%$ of the individuals from 1965-1976, that average length of life was from 2.80 to 3.16 years. Ellenberg (1978) found for roe deer living in an open range that average length of life was 2.72 years, and in a large enclosure of 130 ha over the course of 6 years, length of life varying from year to year for different age classes, from 2.27 to 2.82 years. In both the Danish and German populations density was high, similar to that in Slonin Wood. None of these populations was subject to much game shooting which might have affected the survival of roe deer. There are 
thus grounds for agreeing with Ellenberg (1978) that self-regulation only of the population applies here, stimulated by the productivity of the biotope, and habitat capacity. This author considers that migrations may. play only a small part in such self-regulation, since in country everywhere densely settled by roe deer they cancel each other out. In the case of Słonin Wood this last condition was not given, since as previously stated density of roe deer was several times lower in the wood than in the fields surrounding it.

The completely normal level of effective increase, attaining the value similar to that in numerous other European study populations, of 0.8 fawns per doe of reproductive age, is also significant. It must be assumed that in cases of excessive density the reproductivity index should decrease. Both the facts referred to would appear to confirm the assumption that in the study area density of 50 individuals per 100 ha had not as yet reached the optimum upper limit.

The analysis presented in this paper of the degree of residency of roe deer living in the wood and neighbouring fields showed that the spatial distribution of the population was fairly stable and did not undergo changes even after a population vacuum had been formed. This statement is not, however, sufficiently proved by material in relation to individuals in the young age classes, which at least in the case of bucks formed the main body of migrants.

We cannot find any other sensible explanation than that these were roe deer which in years of low density in the wood, or their complete absence, immigrated into the wooded area from the local field population. It would be difficult to accept that they entered in mass numbers from other small forests situated at a distance of up to $20 \mathrm{~km}$ away, particularly when it is remembered that roe deer are known only rarely to undertake long migrations (Strandgaard, 1972; Neuhaus \& Schaich, 1978; Pielowski, 1983). The roe deer living in small forests quickly tend to reach considerable density, with only a slight tendency to migrate. As shown by the results of transferring roe deer from the wood to fields, a considerable number of them returned to their native forest habitat. In the case of very young animals the tendency to return to the wood was, however, far less distinct. The small numbers of animals concerned unfortunately made it impossible to reach any more definite conclusions.

The estimate, based on complete elimination by shooting, of the quality of the bucks' antlers in the study population gives rise to the following remarks. While the analysis of certain elements of the population structure failed to reveal the negative effects of possible overcrowding of individuals, it would seem that this is evident in the poor quality of antlers, particularly in young bucks. This would agree 
with Pielowski's theory (1970) that in roe deer the antlers form a certain kind of superproduct of the organism for which, depending on the mental state and physical condition of the given individual in the given year, more or less building material is available. The intensified occurrence of yearling bucks with button' spikes only, and the generally weak formation of the antlers in young males is a characteristic of debility or of a permanent condition of stress (Raesfeld et al., 1978; Stubbe \& Passarge, 1979). In the case in question the first of these eventualities, which might have been the consequence of poor feeding conditions etc., does not apply. Measurements of the body weight of shot roe deer and biometrical measurements (unpublished data from the Polish Hunting Association Research Station) showed that the animals' physical development took a completely normal course. It is, however, most likely that under the prevailing overcrowding conditions there were a great number of conflict situations among bucks during the spring-summer territorial life. It is males in the younger age classes which are then in the worst hierarchical situation of the social structure, which according to Henning (1962) and Kurt (1968) has an unfavourable effect on development of the antlers. The fact that normally developed antlers predominated among bucks in the older age classes provides confirmation of this.

Quite apart from the basic purpose of the study, its results would appear to supply some more data contributing to a better knowledge of the roe deer's ecology in general. For instance it supplied yet another proof, after the papers by Strandgaard (1972), Bobek et al. (1977), Pucek et al. (1975), Ellenberg (1978) and Pielowski (1979) of the truly enormous underestimation of the density of roe deer in a forest when the method of "by sight and by intuition" is applied. There can surely be no doubt that the roe deer, even though revealing its presence with little timidity, is still a species leading a very hidden way of life. The density found in 1975 of almost 52 individuals per 100 ha or the average density for 1977-1980 of 32 individuals per 100 ha is the best proof of how great, under given conditions of shelter and food, the capacity of a forest habitat may be for roe deer far exceeding all "official" standards (Bobek et al., 1977). The abundant food supply available almost all the year round in the field adjoining the wood cause the roe deer inhabiting the wood to obtain the majority of the food they need outside it. Under these circumstances forest plantations do not exhibit an excessive degree of destruction by these animals, since the food supply in them is in no way competitive with the abundant food supply in nearby fields.

Another contribution to methods for further studies on the roe deer would appear to be the comparison made of the picture of age structure, 
obtained by defining the age of all individuals in the population (total elimination by shooting) with the age structure obtained from material supplied by long-term normal shooting for hunting purposes. They differ to a marked degree. This may be an indication of the very limited usefulness of material from planned game shooting, governed by a large number of regulations, for defining the age structure of a roe deer population.

On the basis of the material presented and the above discussion the statement may be put forward that in the roe deer's living habitat of the field ecotype, that is, in agrocenoses, small forests have a special additional importance for this species. As a result of the excellent living conditions formed by, inter alia, the presence of a very advantageous and extensive zone of the ecotone - a wooded are (shelter), fields (food), considerable density of roe deer rapidly is achieved in such small woods by means of immigration, and greatly exceeds that in the neighbouring entirely field areas. Emigration of individuals into field areas would appear to be slight and applies mainly to the young age classes. It would probably become greater if density reached an even higher level. In the phase of its quantitative stabilization, the head of roe deer in a small forest constitutes a sub-population with a considerable degree of ecological isolation from the roe deer population surrounding it in the fields. It is, however, formed, or may at least be supplemented, from the large group of migrants from fields. The attractive nature of small forest biotopes on the one hand, and on the other perhaps the as yet not completely lost instinctive tie between this species and a forest habitat, forms a certain predilection in roe deer living in fields to search for their preferred places of shelter in a wood. It would be possible to go even further in these discussions, by assuming that this applies primarily to all such individuals in which the ethological pattern of the representative of the field ecotype of roe deer is not yet sufficiently imprinted. If this is so, it means that small forests, as a habitat intermediate between larger stretches of wooded land and open fields, play an important part in the process of ecological differentiation of this species.

\section{REFERENCES}

1. Andersen A. L., 1953: Analysis of a Danish roe-deer population. Danish Rev. Game Biol., 2: 121-155.

2. Andrzejewski R. \& Wroclawek H., 1962: Settling by small rodents a terrain in which catching out had been performed. Acta theriol., 7: 257-247.

3. Bobek B., Dzięciołowski R., Fruziński B., Pucek Z. \& Tomek A., 1977: Raport o stanie zwierzyny grubej. Łowiec pol., 6: 3-4. 
4. Caughley G., 1966: Mortality patterns in mammals. Ecology, 47: 906-918.

5. Ellenberg H., 1978: Zur Populationsökologie des Rehes (Capreolus capreolus L. Cervidae) in Mitteleuropa. Z. Zool., Spixiana, Suppl., 2: 1-211.

6. Fruziński B., Łabudzki L. \& Wlazełko M., 1983: Habitat, density and spatial structure of roe deer population in forest. Acta theriol., 28.

7. Hennig F., 1962: Uber das Revierverhalten der Rehböcke. Z. Jagdwiss., 8: $61-81$.

8. Kałuziński J., 1978: Odłowy sarn w sieci. Łowiec pol., 18: 7, 11.

9. Kałuziński J., 1982: Dynamics and structure of a field roe deer population. Acta theriol., 27: 385-408.

10. Kurt F., 1968: Das Sozialverhalten des Rehes. Mammalia depicta, Paul Parey Verlag: 1-102. Hamburg.

11. Mottl S., 1962: Zur Frage der Wilddichte und der Qualität des Rehwildes. Beitr. Jagd- und Wildforsch., 2: 35-40.

12. Pielowski Z., 1970: Sarna - monografia przyrodniczo-łowiecka. Państw. Wyd. Roln. i Leśne: 1-220. Warszawa.

13. Pielowski Z., 1977: Das Feldreh - Wild der Zukunft in der Agrarlandschaft. Beitr. zur Jagd- und Wildforsch., 10: 193-200.

14. Pielowski Z., 1979: Drugi rok działalności „Zespołu Hodowli Zwierzyny Grubej” na terenie Nadleśnictwa Smolarz. Łowiec pol., 17: 3-4.

15. Pielowski Z., 1983: Niektóre aspekty struktury populacji sarny polnej zbadane drogą wizualnego znakowania osobników. Acta theriol., 28.

16. Prior R., 1968: The roe deer of Cranborne Chase. Oxford Univ. Press: $1-215$, London.

17. Pucek Z., Bobek B., Łabudzki L., Miłkowski L., Morow K. \& Tomek A., 1975: Estimates of density and number of ungulates. Polish Ecol., Stud., 1: 121-136.

18. Raesfeld F., Neuhaus A. H. \& Schaich K., 1978: Das Rehwild. Verlag Paul Parey: 1-392. Hamburg und Berlin.

19. Strandgaard H., 1972: The roe-deer (Capreolus capreolus) population at Kalö and the factors regulating its size. Danish Rev. Game Biol., 7: 1-205.

20. Stubbe C. \& Passarge H., 1979: Rehwild. VEB Deutscher Landwirtschaftsverlag: 1-432. Berlin.

Accepted, July, 29, 1982.

Zygmunt PIELOWSKI i Wojciech BRESINSSKI

CHARAKTERYSTYKA POPULACYJNA SARN LASU SRODPOLNEGO

Streszczenie

W ramach kompleksowych badań nad określeniem istoty ekotypu sarny polnej, w latach 1975-1980 przeprowadzono badania których celem było sporządzenie charakterystyki populacyjnej sarn zasiedlających kompleks lasu śródpolnego i ustalenie na tym tle, w jakim stopniu ugrupowanie to wyróżnia się od otaczającego go pogłowia sarn polnych i jakie są wzajemne uzależnienia i oddziaływania tych subpopulacji. Każdego roku przeprowadzano szczegółową ocenę ilościową i jakościową badanej populacji. W celu śledzenia ruchów migracyjnych sarn pomiędzy lasem a polami oraz dla określenia stopnia osiadłości osobników zastosowano in- 
dywidualne znakowanie i eksperymentalne obniżenie zagęszczenia sarn $w$ lesie prawie do zera.

Stwierdzono, że zagęszczenie sarn $\mathrm{w}$ tym lesie $\mathrm{w}$ okresie stabilizacji ilościowej było wielokrotnie wyższe niż w otaczającej populacji polnej (Fig. 1, Tabela 1). Uzyskano realny obraz struktury wiekowej (Fig. 2), wyliczono też oczekiwany dalszy czas życia sarn w poszczególnych klasach wiekowych (Tabela 2). Stwierdzono duży stopień osiadłości osobników tworzących ugrupowanie leśne (Tabela 3). W momentach obniżonego znacznie zagęszczenie sarn $w$ lesie zachodzi silna emigracja $z$ terenów polnych, które $w$ takiej sytuacji formują pogłowie na nowo lub też kompletują jego stan liczebny do odpowiednio wysokiego zagęszczenia. Migranci to głównie osobniki młode. Imigracja z lasu na pola wydaje się być niewielka.

Zjawisko to znajduje tłumaczenie w dużej atrakcyjności biotopów lasów śródpolnych, obfitujących $\mathrm{w}$ strefę ekotonu pole-las oraz $\mathrm{w}$ instynktownej więzi sarn z pierwotnym środowiskiem leśnym. W rezultacie badań stwierdza się, że w środowisku życiowym sarny polnej - w krajobrazie rolniczym, lasy śródpolne jako środowisko pośrednie pomiędzy większymi kompleksami leśnymi a otwartymi polami odgrywają poważną rolę w procesie ekologicznego zróżnicowania się gatunku. 